\begin{abstract}
М.А. Овчарова*
Устноисторические источники

в изучении земледельческих миграций мордвы и формирования поселений в восточной части Сибири в 1930-1940-е годы
\end{abstract}

DOI: $10.31518 / 2618-9100-2020-5-6$

УДК 94(47).084.6+94(47).084.8

Выходные данные для цитирования:

Овчарова М.А. Устноисторические источники в изучении земледельческих миграций мордвы и формирования поселений в восточной части Сибири в 1930-1940-е годы // Исторический курьер. 2020. № 5 (13). С. 70-82. URL: http:// istkurier.ru/data/2020/ISTKURIER-2020-5-06.pdf
M.A. Ovcharova*

\section{Oral History Sources in the Study of Agricultural Migrations of the Mordvins and Formation of Settlements in the Eastern Part of Siberia in the 1930s-1940s}

\author{
DOI: 10.31518/2618-9100-2020-5-6
}

\section{How to cite:}

Ovcharova M.A. Oral History Sources in the Study of Agricultural Migrations of the Mordvins and Formation of Settlements in the Eastern Part of Siberia in the 1930s-1940s // Historical Courier, 2020, No. 5 (13), pp. 70-82. [Available online:] http://istkurier.ru/data/2020/ISTKURIER-2020-506.pdf

Abstract. In the Soviet Union, much attention was paid to the planned migration policy from different regions, in which a wide variety of ethnic groups participated. Until recently, issues related to certain aspects of resettlement have not been fully studied. This is often due to a lack of a source base. This was especially true for to the agricultural settlers from the European part of Russia, the Mordvins, Chuvash, Komi-Permians, who rushed to the Siberian region. Agricultural settlers of the Soviet period became a new stream that formed zones of mono-ethnic and mixed regions of residence of the Mordvins and Chuvash people in the region. To form a complete picture of this period, a versatile source base is required, since only the totality of source data will allow us to present the historical process of gradual migration of the Mordvins to the regions of Siberia. As a result of an oral history interview, the author was able to build a historical chain of formation of the artisanal settlement of the Mordvins-Moksha on the territory of the Krasnoyarsk territory, the Altai region of Khakassia.

Keywords: oral history; historical interviews; media; agricultural migrations of the mordvins; mono-ethnic settlements.

The article has been received by the editor on 07.07.2020.

Full text of the article in Russian and references in English are available below.

Аннотация. В Советском Союзе уделялось большое внимание планово-переселенческой политике из разных регионов, в которой принимали участие самые различные этносы. До последнего времени вопросы, связанные с отдельными аспектами переселений, изучены не до конца, часто из-за нехватки источниковой базы. Особенно это связано с сельхозпереселенцами из Европейской части России - мордвой, чувашами, коми-пермяками, которые устремились в Сибирский регион. Сельхозпереселенцы советского периода стали новым потоком, который формировал в регионе моноэтнические и смешанные зоны проживания мордвы и чувашей. Для создания полноценной картины по этому периоду требуется разносторонняя источниковая база, которая позволит представить исторический процесс поэтапного переселения мордвы в регионы Сибири. В результате проведения устноисторических

\footnotetext{
* Овчарова Мария Александровна, кандидат исторических наук, Новосибирский государственный краеведческий музей, Новосибирск, Россия, e-mail: masha pa@mail.ru

Ovcharova Maria A., Candidate of Historical Sciences, Novosibirsk State Museum of Local History, Novosibirsk, Russia, e-mail: masha_pa@mail.ru
} 
интервью нам удалось выстроить историческую цепочку формирования кустарного расселения мордвы-мокша на территории Красноярского края, Алтайского района Хакасии.

Ключевые слова: устная история; историческое интервью; носители информации, сельскохозяйственные переселения мордвы; моноэтнические поселения.

История Сибирского региона в XIX - первой половине XX в. была связана с миграциями, которые играли важную роль в ее хозяйственном освоении. В Сибирском регионе в XIX - во второй половине XX в. в результате массового переселенческого потока формировалось многонациональное сообщество. Государство на протяжении всего периода выступало основополагающим организатором перемещения больших масс людей (организованных миграций). В это время в них принимали участие представители разных этносов. Масштабы и районы расселения менялись в зависимости от природно-географических предпочтений новоселов, государственных планов. В исследовательской публикации на основе разных источников рассказывается о государственной кампании переселений конца 1930-х - начала 1940-х гг., когда земледельческое население из восточных районов страны стихийно и массово направлялось в еще плохо заселенные регионы Сибири. Советская власть за период 1920-1960-х гг. предприняла разные масштабные виды перемещения людей по стране: плановые, массовые, принудительные. Движения людей всегда являлись государственной политикой и влекли за собой сложное сочетание политических и экономических факторов. В опубликованных трудах историков, занимающихся проблематикой переселенческой политики СССР (Н.И. Платунов, П.М. Полян, Л.В. Зандалова, С.А. Красильников и др.) ${ }^{1}$ в государственных земледельческих переселениях выделяются три этапа: переселения 1920-х начала 1930-х гг., плановое переселение колхозников из малоземельных районов СССР в 1939-1942 гг., переселения на целинные и залежные земли в 1954-1960 гг. Мордовские переселенцы на протяжении всего XX в. активно принимали участие в переселенческом движении, и работа с устноисторическим материалом помогает восстановить все малоизученные аспекты.

Отдельные особенности и этапы заселения мордвой разных регионов Сибири изучены с разной полнотой. Из-за непроработанности и нехватки источников не до конца освещенным остается вопрос переселения мордвы в Сибирь в советское время. Конечно, в последнее время стали появляться исследования о переселении немцев Поволжья, калмыков, украинцев, белорусов ${ }^{2}$. Однако помимо этих народов в Сибирь было отправлено большое количество мордвы, чувашей, коми-пермяков.

Ученые, историки, включенные в анализ разных аспектов миграционных процессов, много внимания уделяли изучению планово-переселенческой политики и насильственной депортации в Советском Союзе. Современные исследователи освещают различные аспекты насильственной миграции советского периода в Сибирь. Не вдаваясь в тематическую историографию, необходимо отметить, что в ней в основном освещена социально-политическая проблематика вопроса. Отдельные исследования были связаны с этническими спецпересе-

\footnotetext{
${ }^{1}$ Полян П.М. «Не по своей воле...» История и география принудительных миграций в СССР. М., 2001. 244 с.; Красильников С.А. Государственная политика в сфере плановых и принудительных переселений в Сибири (вторая половина 20-х - 1930-е годы) // Проблемы истории, русской книжности, культуры и общественного сознания. Новосибирск, 2000. С. 314-322; Занданова Л.В. Переселение крестьянства в Азиатскую Россию: (конец 1940-х - сер. 60-х гг. ХХ в.). Иркутск, 1997. 157 с.; Платунов Н.И. Переселенческая политика советского государства и ее осуществление в СССР (1917 - июнь 1941 г.). Томск, 1976. 282 с.

2 Занданова Л.В. Переселение крестьянства в Азиатскую Россию: (конец 1940-х - сер. 60-х гг. ХХ в.). Иркутск, 1997. 157 с.; Иванов А.С. Калмыки в Западной Сибири (1944-1956 гг.): особенности социализации на спецпоселении // Вестник археологии, антропологии и этнографии. 2011. № 2 (15). С. 210-217; Полян П.М. «Не по своей воле...»...; Бережнова М.А. Государственная программа переселений в восточные районы СССР 1939-1942 гг.: этнографический аспект // Известия Алтайского государственного университета. (История и археология). № 4/2. 2008. С. 7-15; Овчарова М.А. Мордва Алтая: История и этнокультурные процессы (XIX - начало XXI века). Новосибирск, 2010. 228 с.
} 
ленцами: немцами, евреями, калмыками, были попытки изучения этнического состава переселенцев 1920-х гг. В настоящее время наиболее полно изучена немецкая диаспора Сибири. Остальные переселенческие потоки изучены неполноценно, в т.ч. и их этнический состав. Миграции советского периода чувашей и мордвы до недавнего времени не были освещены в исследованиях. Поэтому объединение разных видов источников может восполнить пробелы в изучении движения этих этносов в советское время. Существующий перекос в историографии в изучении плановых и насильственных переселений решается современными исследователями. В работах авторов указывается, что самой массовой формой миграций в России в первой половине XX в. были индивидуально-стихийные крестьянские переселения. Исследованию этих процессов был посвящен междисциплинарный проект сибирских и дальневосточных ученых «Миграционные процессы в Азиатской России в XIX - начале XXI в.» ${ }^{3}$, в котором ученые попытались рассмотреть разные аспекты, связанные с перемещением людей. Результатом стал выход двух интереснейших сборников статей, в которых анализируются добровольно-вынужденные миграции, сыгравшие определяющую роль в заселении, аграрном и промышленном освоении Азиатской России. Для нашей работы интересны и важны работы таких исследователей, как М.А. Шиловский ${ }^{4}$, который в своей статье определяет все хронологические границы внешних миграций, раскрывая их последствия. Социальных аспектов миграций в Сибирь в первой трети XX в. в своей работе касается В.А. Ильиных 5 . Подробно на добровольно-вынужденных миграциях в Западную Сибирь, их проблематике, развитии на протяжении 1920-1940-х гг., а также процессах перемещения населения из села в город в своих исследованиях останавливался В.А. Исупов ${ }^{6}$. Важным источником, позволяющим восстановить картину внешних миграций мордвы на территорию Западной Сибири, являются архивные документы Государственного архива Новосибирской области (далее - ГАНО), в частности материалы Переселенческого управления Западно-Сибирского краевого Совета депутатов и Отдела хозяйственного устройства эвакуированного населения исполнительного комитета Новосибирского Совета депутатов трудящихся. При изучении советского времени и переселенческих процессов, основная часть исследователей опирается на ограниченные источники. Очень часто статистическими источниками выступали материалы переписей - 1926, 1939, 1959 гг., каждая из которых имела свои особенности и специфику. Наиболее информативной для исследователя была только «Всесоюзная перепись населения 1926 года», поскольку в ней учитывались такие категории, как национальность, родной язык и место рождения ${ }^{7}$ Кроме того, по результатам переписи 1926 г. был опубликован очень важный документ «Список населенных мест 1926 года»", в котором в отличие от предыдущих Списков 1886 г., 1911 г. и др. населенные пункты указывались с преобладающей национальностью. Дальнейшие советские переписи были менее подробными, а результаты переписи 1937 г. были объявлены недействительными. Задачей данной статьи является показать формирование и использование устноисторического источника при исследовании внешних сельскохозяйственных переселений мордовского населения в Восточную Сибирь в конце 1930-х - начале 1940-х гг., как они дополняют документальные источники и позволяют представить полноценную картину

\footnotetext{
${ }^{3}$ Миграции населения Азиатской России: конец XIX - начало XX в. / отв. ред. В.А. Исупов. Новосибирск, 2011. 392 с.

${ }^{4}$ Шиловский M.В. Основные потоки внешних миграций в истории Сибири XX века // Миграционные процессы в азиатской России в XIX - начале XXI в.: сб. науч. тр. / отв. ред. В.А. Исупов. Новосибирск, 2009. С. 32-44.

${ }^{5}$ Ильиных В.А. Социальные аспекты миграционных процессов в Сибири первой трети ХХ века // Миграционные процессы в азиатской России в XIX - начале XXI в.: сб. науч. тр. / отв. ред. В.А. Исупов. Новосибирск, 2009. С. 44-53.

${ }^{6}$ Исупов В.А. Индивидуальные крестьянские переселения в города Западной Сибири (конец 1920-х - начало 1940-х гг.) // Миграционные процессы в азиатской России в XIX - начале XXI в.: сб. науч. тр. / отв. ред. В.А. Исупов. Новосибирск, 2009. С. 66-93.

${ }^{7}$ Всесоюзная перепись населения 1926 год. Отдел. 1. М., 1928. Т. VI. Сибирский край. Бурято-Монгольская АССР. (Население по народности, родному языку). 389 с.

${ }^{8}$ Список населенных мест Сибирского края. Округа Юго-Западной Сибири / ЦСУ. Сибирский Краевой статистический отдел. Новосибирск, 1928. Т. 1. 831 с.
} 
происходящих исторических процессов. В ходе проведения полевых исследований и интервью потомки переселенцев воспроизводили историю своей семьи с этапами переселения, вспоминали своих предков, места выхода, хорошо очерчивали события, связанные образованием новых поселений, расселением, процессом ликвидации «неперспективных сел». Изучение исторических фактов, заполнение лакуны в исследовании переселенческих процессов в Сибири позволит определить четкие векторы расселения на новых местах, принятие или непринятие переселенцев «старожилами», картину их приживаемости, не останавливаясь на переселенческой политике советского государства 1920-х гг., когда оно пыталось справиться с нарастающим стихийным переселенческим потоком из европейской части России.

В этой ситуации в 1925 г. Всесоюзный переселенческий комитет совместно с Наркомземом проработали новую политику на 1926-1936 гг., которая предполагала открыть Сибирский край для переселенцев. В сложной экономической ситуации это решало несколько важных вопросов в стране. Эффективно освоить земельные и природные ресурсы Сибирского региона было бы возможным при аграрном перемещении населения из перенаселенных регионов европейской части России. Согласно «Резолюции Сибкрайисполкома о состоянии и перспективах переселенческого дела в Сибири» от 17 декабря 1929 г. определялось: «в связи с использованием в крае громадных производственных ресурсов, в условиях чрезвычайно низкой плотности населения было необходимо осуществить переустройство сельского хозяйства края с включением переселенческого населения. Заготовку колонфондов необходимо было сосредоточить в слабо обжитых районах, главным образом в Томском, Кузнецком, Ачинском, Красноярском и Каннском округах, используя в первую очередь под переселение крупные массивы этих округов, обеспечивающие развитие товарного скотоводческого земледельческого хозяйства, а также развитие посева технических культур, а также социально-культурного обслуживания переселенческих хозяйств» ${ }^{9}$. Добровольно-вынужденные миграции из Поволжья активизировались в 1930-е гг., когда над сельскими жителями нависла проблема продовольственной безопасности. Одним из жестоких явлений этого времени стал голод. Сильные засухи снижали урожайность сельскохозяйственных культур в Мордовии и способствовали распространению голода. С начала 1930-х гг. к природным катаклизмам и росту хлебозаготовок добавляются субъективные государственные обстоятельства в виде коллективизации и репрессий. В сельской местности нехватка продовольствия приводила к трагическим последствиям.

В этот период сельское хозяйство Сибири, огромные необработанные земельные пространства действительно нуждались в новой рабочей силе, расширении крестьянских хозяйств. В то же время центральные регионы страны были перенаселены и не могли в достаточной мере прокормить все имеющееся население. Главную роль в повышении миграционной активности крестьян из этих регионов сыграли коллективизация и голод. В этой ситуации миграции в СССР принимали бесконтрольный характер ${ }^{10}$. Мордва, проживавшая в селах и занимавшаяся в основном сельским хозяйством, при переселении всегда искали зону для поселения схожую и удобную для ведения хозяйства. В этой ситуации новоселы мордва города обходили стороной. Уже к 1920-м гг. мордовские переселенцы довольно массово заполнили этот регион, занимая по численности 4-е место (107 794 чел.) после русских, украинцев, белорусов ${ }^{11}$, из которых 3,6 \% (или 3493 чел.) проживало в городских поселениях и $96 \%$ (90 816 чел.) в сельских. Немалую роль здесь играл и языковой барьер, уровень грамотности. Среди мордвы-эрзя и мордвы-мокша грамотных было всего 21,3\% (20 197 чел.), а на своем языке и того меньше 2,7 \% (2584 чел.) $)^{12}$. Работа в городе требовала знания языка, квалификации, образования, чего у мордвы не было, а мордовские женщины

\footnotetext{
${ }^{9}$ Государственный архив Новосибирской области (ГАНО). Ф. Р-209. Оп. 1. Д. 577. Л. 21-24 об.

${ }^{10}$ Массовые аграрные переселения на восток России (конец XIX - середина XX в.) / Н.Н. Аблажей, С.А. Красильников, Д.Д. Миненков, Г.А. Ноздрин. Новосибирск, 2010. С. 76

${ }^{11}$ Посчитано по: Всесоюзная перепись населения 1926 год. Отдел. 1. М., 1928. T. VI...

${ }^{12}$ Посчитано по: Там же.
} 
вообще слабо владели русским языком, только $29 \%{ }^{13}$. Поэтому, проживая в основном в сельской местности, мордовские переселенцы старались селиться локальными группами, образовывая отдельные поселения или моноэтнические зоны в поселениях. В 1920-1930-е гг. в Сибири начинает складываться чувашское сообщество. Если в середине 1920-х гг. чуваши по численности занимали 8-е место среди этносов региона (48 011 чел.) ${ }^{14}$, то к концу 1930-х гг. их уже числилось около 73000 человек ${ }^{15}$.

Для формирования полноценной картины по этому периоду требуется разносторонняя источниковая база, которая позволит представить исторический процесс того времени. Наличие источников и документов позволяет исследователям говорить о поэтапном переселении мордвы в регионы Сибири; выделять особенности расселения, образования моноэтнических поселений. Начав исследовательскую работу, мы столкнулись с проблемой отсутствия полноценных источников. В своей многолетней полевой работе мы осуществляли сбор этнографических источников, а также использовали методы усноисторических исследований: историческое или исследовательское интервью. В этой ситуации историческое или исследовательское интервью стало практически основным источником по изучению многих поставленных задач, начиная от формирования мордовского этнического массива, заканчивая культурой. Фиксация сохранившихся элементов традиционной культуры, а также интервью с проникновением в этническую ментальность позволяли сформировать базу этнографических и исторических источников по мордве Сибири. Удалось выделить этапность в заселении мордвой Сибирского региона, особенности в расселении, места выхода, демографические особенности и другие аспекты историко-этнографического проживания мордвы в Сибири.

Работая с чувашским этносом в местах локального расселения, мы столкнулись с другой проблемой. В настоящее время уже исчезающий населенный пункт (по воспоминаниям респондентов) когда-то был зоной расселения чувашского этноса. Таким образом, формируемое нами исследовательское интервью нуждается в документальном подтверждении, историческом источнике, чтобы складывалась полноценная картина заселения чувашами исследуемого региона в Кемеровской области.

K 1920-1930-м гг. в Енисейской зоне также сформовалась достаточно большая зона расселения мордвы. При изучении этого вопроса вы столкнулись с недостаточным количеством опубликованных материалов и документальных источников. В новейшей литературе хорошо освещены опросы, связанные с социально-политическими аспектами миграции крестьян в этот регион. Этнический состав переселенцев специально не исследовался. Именно устноисторический источник помогает нам определить, опираясь на документальные источники, районы расселения и особенности государственной кампании 1938 г. в Восточной Сибири для мордовского этноса. Устноисторический источник создавался в процессе исторического интервью. Полевые исследования проводились в 2012 г. в селах с компактным проживанием мордовского населения: Краснополье и Подсинее Алтайского района Хакасии. Основными методами работы было интервьюирование и этносоциологическое анкетирование.

Добровольные плановые переселения крестьян в Сибирские регионы были возобновлены в 1933 г. В этот период Всесоюзный переселенческий комитет перешел в ведение Совнаркома, на местах были созданы аппараты уполномоченных - переселенческие отделы. Изменения политической обстановки в стране, произошедшие в конце 1938 - начале 1939 г., отразились и на переселенческой политике государства: по решению ЦК ВКП(б) и СНК СССР 27 мая 1939 г. были ликвидированы Бюро по сельскохозяйственному переселению Наркомзема и Переселенческий комитет НКВД. Взамен ранее существовавших структур была создана единая общесоюзная организация - Переселенческое управление при СНК

\footnotetext{
${ }^{13}$ Посчитано по: Всесоюзная перепись населения 1926 год. Отдел. 1. М., 1928. T. VI...

${ }^{14}$ Посчитано по: Там же.

${ }^{15}$ Всероссийская перепись населения 1939 года. Национальный состав населения районов, городов и крупных сел РСФСР [Электронный ресурс]. URL: www.demoscope.ru
} 
СССР. В связи с достаточно сложной экономической обстановкой в Поволжье, переселенческое движение оттуда в регионы Сибири в этот период было достаточно массовым. На территории Мордовии новая волна голода началась уже зимой 1936/1937 г. На фоне серьезного кризиса с обеспечением продовольствием власти требовали выполнить при низком урожае зерновых культур обязательные поставки. Неурожай 1936 г. вызвал снижения численности поголовья скота на территории Мордовии. Последующие за этим события были связаны с повышением уровня смертности. Увеличивалось количество больных сыпным тифом и дизентерией.

Катализатором переселенческого движения на данном этапе стало постановление партии и правительства от 27 мая 1939 г. «О мерах охраны общественных земель колхозов от разбазаривания» ${ }^{16}$. Основная суть постановления сводилась к тому, что в колхозах была введена четкая фиксация земельного фонда, в т.ч. размеров приусадебных участков. К этому периоду земельный фонд в европейской части России был значительно исчерпан. У крестьян просто не имелось никакого приусадебного участка. В стране возникла острая потребность перераспределения трудовых ресурсов в те регионы, где их не хватало и в то же время было достаточно земли. Основной переселенческий поток направлялся в многоземельные районы, такие как Омская и Челябинская, Новосибирская области, Алтайский край, Казахстан и др. Мордовия в то время отставала в социально-экономическом развитии от передовых регионов страны, вследствие чего часть населения покидала пределы республики в поисках более обеспеченной жизни и квалифицированного труда ${ }^{17}$. Многие колхозы в малоземельных районах были уже не в состоянии наделять приусадебными землями колхозников по норме, предусмотренной Уставом, поэтому намечалась организация переселения колхозников из малоземельных районов в многоземельные - Омскую, Новосибирскую, Челябинскую области, Алтайский край, Казахстан, на Дальний Восток. Переселенческое управление при СНК СССР отмечало, что по материалам, полученным от начальников эшелонов, проверивших целый ряд колхозов, а также по материалам Переселенческих отделов была видна исключительная активность переселенцев по приезду в колхозы вселения. Как правило, переселенцы немедленно включаются в самую активную производственную жизнь колхозов, полностью все выходят на работу. Представитель одной из групп переселенцев, прибыв на Дальний Восток, писал: «Встретили нас как дорогих, желанных гостей - уже на вокзале нас встречали представители рабочих организаций, руководители города и района. За несколько дней до нашего приезда в колхозах для нас приготовили квартиры, подвезли к ним дрова, сено, мы получили коров, скот, птицу. О нас заботятся, нас любят, нам создают все условия» ${ }^{18}$.

В это время сельскохозяйственное переселение в основном носило плановый характер, но присутствовали и неорганизованные переезды. В районы Дальнего Востока и ряд других районов в 1940 г. внепланово переселились более 16 тыс. хозяйств.

В конце XIX - первой половине XX в. в границах современного Красноярского края и Хакасии сформировалась сеть мордовских поселений. Местами их наибольшего скопления стала зона вокруг г. Минусинска, а также на территории нынешних Идринского, Каратузского, Краснотуранского, Ермаковского районов Красноярского края и Алтайского района Хакасии, некогда входивших в состав обширной Енисейской губернии. На конец XIX в. основная часть населенных пунктов с мордовским населением числилась на территории Минусинского округа Идринской волости, в частности в дер. Петропавловская, дер. Козинская, дер. Березовская, дер. Саблинская; Тесинской волости: дер. Верхняя Коя, Большая Ничка, Жарлык и др ${ }^{19}$.

\footnotetext{
${ }^{16}$ Массовые аграрные переселения на восток России... С. 77.

${ }^{17}$ Надькин Т.Д. Сталинская аграрная политика и крестьянство Мордовии. М., 2010. С. 151-152.

${ }^{18}$ Восточный вектор переселенческой политики в СССР. Конец 1920-х - конец 1930-х гг. Новосибирск, 2007. C. 258.

${ }^{19}$ Список населенных мест Российской империи по сведениям 1859 года. Енисейская губерния. СПб., 1864 г. T. 51.74 c.
} 
Освоение мордовскими переселенцами территории Енисейской зоны по сравнению с другими регионами Сибири началось достаточно поздно. До конца XVII в. из-за частых войн с местным населением постоянные поселения в этом регионе не создавались. K этому добавлялись особые природно-географические условия региона, где представлены все зоны от степи до тайги и лесотундры с резко континентальным климатом.

Мордва при выборе мест поселения учитывала много различных факторов: землю, наличие леса, источник пресной воды. Мордовские переселенцы очень часто оседали в лесостепной полосе, тянувшейся от южного Урала до Алтая, в восточно-приалтайской части, входившей в состав Томской губернии. С заселением удобной земли переселенцы переходили на участки в степной и таежной зонах. Наиболее активно заселяющейся территорией была зона Минусинского округа, что способствовало превращению его в один из главных сельскохозяйственных районов Восточной Сибири. В подтаежных деревнях крестьяне занимались лесными промыслами. Активный приток мордовских переселенцев на территорию Енисейской губернии начинается с конца XIX - начала XX в. - периода Столыпинской реформы. Мордва осваивала подтаежные земли на северо-востоке округа. В верховьях рек Сыда и Шушь ими были основаны деревни Козино и Петропавловка. Материалы по землевладению и землепользованию этого периода свидетельствуют, что основной социальной фигурой переселенцев из Мордовии являлась крестьянская беднота.

Регион локального расселения мордвы-мокша в Красноярском крае является зоной более позднего переселенческого потока, по сравнению с другими регионами Сибири. В конце XIX в. численность мордвы в Томской губернии составляла 14702 чел, Енисейской губернии 3773 чел. ${ }^{20}$ В 1926 г. в Красноярском крае уже числилось 16655 чел. Мордвы, в то же время на современной территории Алтайского края 49467 чел., Кемеровской области 17527 чел ${ }^{21}$. К 1939 г. ситуация меняется, в Красноярском крае (вместе с территорией Хакасии) уже числилось 28884 чел. мордвы ${ }^{22}$. Переселенческие потоки мордвы 1930-1940-х гг. на территорию Красноярского края были связаны с разными аспектами политики советского государства. Постановлением 1925 г. было открыто плановое переселение из малоземельных регионов Европейской части России в Сибирь и на Дальний Восток. Изменение переселенческой политики в 1938-1939 гг., было связано с расширением колхозного строительства и переселением колхозников из малоземельных регионов в многоземельные районы Сибири. Колхозное строительство сыграло важную роль в увеличении переселенческого потока на территорию Краснодарского края.

В Хакасии зоной компактного расселения мордвы-мокша и коми-зырян стал Алтайский район с селами Подсинее, Краснополье. Одними из образователей мордовской части села Краснополье были переселенцы мордва-мокша из дер. Алексеевка Каратузского района Красноярского края. В дальнейшем при образовании колхозного поселения в 1930-1940-е гг., в Краснополье хлынул поток переселенцев мордвы-мокша, которые были выходцами из Республики Мордовия, Ельниковского района, дер. Каньгуши, дер. Верхние Пошаты, Пошаты. Основной причиной переселения был голод, бедность в предвоенные годы, а «по рассказам родственников, здесь пшеницу лопатами гребли» ${ }^{23}$ (Осипова М.С., 1927 г.р., с. Краснополье, мордва-мокша).

В результате устно-исторического интервью нам удалось выстроить историческую цепочку формирования кустарного расселения мордвы-мокша на территории Алтайского района Хакасии. Первоначальные мордовские поселения сформировались в с. Алексеева Каратузского района. Это село являлось одним из самых первых мордовских поселений в этой зоне. Из интервью Полины Иосифовны Кудашкиной (в девичестве Ивашкина)

\footnotetext{
${ }^{20}$ Посчитано по: Первая всеобщая перепись населения Российской империи 1897 г. / под. ред. Н.А. Троицкого. СПб.: Издание Центрального статистического комитета Министерства внутренних дел. 1899-1905. T. LXXXIII. Енисейская губерния. 185 с.

${ }^{21}$ Посчитано по: Всесоюзная перепись населения 1926 год. Т. VI...

${ }^{22}$ Всероссийская перепись населения 1939 года...

${ }^{23}$ Полевые материалы автора (ПМА). Полевой дневник, 2012 г. Республика Хакасия, Алтайский район, с. Краснополье. Осипова М.С., 1927 г.р., мордва-мокша.
} 
(1930 г.р.): «родилась в с. Алексеевка. Раньше это был Сабченский участок, там жили когдато тюремщики. Там горы, тайга. Их туда на ссылку отправляли. После ссылки они там оставались. Потом стала туда мордва приезжать, потянулась. Земля была, налог не брали, лес был, деготь гнали! Помню, ребятишками кору собирали. Пшеница там не росла, сеяли коноплю, лен и потом меняли на пшеницу. Ребятишками, соберём корю, отдаем мужуку, а он конфеты давал. Мои деды, бабушка Мария Ивановна Кудашкина, туда переехали еще в ту первую войну из села Пошаты. Затем вокруг него образовывались мордовские поселки Таловка, Верхний Кужебар» ${ }^{24}$.

Поток мордовских переселенцев в этот регион был всегда стабильным, но не сравнимым с более южными районами Алтайского края и Кемеровской области. Увеличение его как раз связано с предвоенными переселениями 1939-1941 гг., когда из Мордовии выезжали целые деревни. Так, в настоящее время Краснополье Алтайского района Хакасии можно назвать селом с преобладанием мордвы-мокша. А по воспоминаниям респондентов в 1960-1970-е гг. это была мордовская деревня, и мордовская речь звучала повсюду. В 1939-1941 гг. в него переселилось более 150 семей из Мордовии. Так, Елена Кузьмовна Кетова (Икомасова), 1927 г.р., вспоминает: «Родилась я в Мордовии, и еще 3 сестры в селе Каньгуши. Там был голод, земли не было. Отец съездил на Урал, там ему не понравилось, а здесь жили родственники, Митяйкины писали, что хорошо! Мы с семьей переехали в 1941 год, только переехали, и сразу началась война. Отца сразу взяли в трудармию. Рядом с дер. Краснополье был поселок Заготскот (там был совхоз). Из нашей деревни сюда приехало много семей: Грызины, Тюркины, Михеевы, Жумкины. В совхозе жили, работали, пахали на быках. Это был совхоз, здесь деньги платили, в Краснополье был колхоз, там ставили трудодни. Нашей семье дали избушку из пластов» ${ }^{25}$. Семья Елены Ивановны Михеевой, 1934 г.р. (мордва-мокша) также переселилась из с. Каньгуши в 1940 г.: «рассказывали, что голод был, земли не было. Дедушка (Грызин Николай Михайлович) поехал, тут место посмотрел и перевез нас. Много народу тогда переехало, Автайкины переехали. Помню, ехали на поезде со станции Ковылкино. Доехали до Абакана, потом на лошадях, «свои» встретили и привезли. Потом дом купили, землянку с одним окошком. Землянка из земляных пластов. Деревня большая была, но деревянных домов не было... были «топтанки», да из земляных пластов, саманы строили из больших кирпичей» ${ }^{26}$. Рядом был колхоз Красный плуг, где жили одни зыряне, которые переселились из Коми-АССР. В Краснополье приехала мордва, и из с. Алексеевка семьи Тимошкиных, Натейкиных.

Таким образом, в ходе полевых работ нам удалось зафиксировать локальную историю перемещения больших групп людей. В памяти людей зафиксировались воспоминания о важном этапе в их жизни. В то время они были еще детьми. Исходя из их воспоминаний, можно сделать вывод, что проживание в земляных домах и тяжелая работа на быках по сравнению с голодом и отсутствием земель в Поволжье казалась им благом, и жить им в сравнении с Поволжьем было лучше и легче. Можно на основе более двух десятков интервью сделать выводы о глобальных переселениях. Только в этот регион из Ельниковского района Мордовии выехало три деревни. Конечно, никто им не готовил дома́, было временное жилье. Из рассказов Полины Иосифовны Кудашкиной понятно, что что их расселили просто в голую степь: «приехали, ничего у нас нет, только кути с вещами. Отец и брат его стали сразу делать дом из земли. Из земли было все... и двор для скота. А в баню ходили к соседям украдкой, как они помоются. В доме окно было одно. Зимой страшно заметало, почти до самой крыши, весной все промокало... деревянные дома стали появляться только в

\footnotetext{
${ }^{24}$ ПМА. Полевой дневник, 2012 г. Республика Хакасия, Каратузский район, с. Алексеевка. Кудашкина П.И., 1930 г.р., мордва-мокша.

${ }^{25}$ ПМА. Полевой дневник, 2012 г. Республика Хакасия, Алтайский район, с. Краснополье. Кетова Елена Кузьмовна, 1927 г.р., мордва-мокша.

${ }^{26}$ ПМА. Полевой дневник, 2012 г. Республика Хакасия, Алтайский район, с. Краснополье. Михеева Елена Ивановна, 1934 г.р., мордва-мокша.
} 
1960-х гг.» ${ }^{27}$ Условия работы были очень тяжелые, одинаковые для женщин и для мужчин. Тем более это было время войны, пахали на быках, работали в тайге на лесозаготовках.

Результаты исследования показали, что важным фактором сохранности этнической идентичности у мордвы являлось бытование языка. В результате исследования удалось определить, что язык является этнодифференцирующим признаком $100 \%$ респондентов. По воспоминаниям информаторов, широкому бытованию в данном случае мокшанского языка способствовало сохранение моноэтнического состава сел до конца 1960-х гг. В 1926 г. в с. Краснополье Минусинского района (современный Алтайский район Хакасии) из 36 дворов 26 являлись мордовскими, остальные - коми-пермяков ${ }^{28}$. С послевоенного времени в селе стало появляться русскоязычное население. Это в основном были присланные специалисты, учителя, врачи, инженеры и др.

По данным ведомственного архива Краснопольской администрации Алтайского района Хакасии, в деревне Краснополье в 2012 г. проживали 32 мордовских семьи и 15 комипермяков. По воспоминаниям информаторов благоприятным периодом для сохранения национального языка выступало время до середины 1960-х годов. Многие информаторы рассказывают, что в селах преобладал моноэтнический состав населения, общались на мокшанском языке, плохо владели русским языком. Жители села 1960-х гг. рождения (Н.Н. Алексеенко, 1960 г.р., мордва-мокша) вспоминают: «учителям тяжело с нами было, сидим, ничего не понимаем. Потом родителям стали приказывать, с детьми дома говорить только на русском. Они старались, а вот бабушка, она ни одного слова по-русски не знала» ${ }^{29}$.

Переход на русский язык, изменения в системе образования повлияли на трансформацию традиционной культуры. Это все повлекло изменения традиционного этнического самосознания мордвы. Сельские жители по разным причинам теряли информационную, духовную связь с этнической родиной. Впитывали бытовой язык, русские традиции. В Минусинской зоне эти тенденции усугубило отсутствие единого мордовского национально-культурного центра.

Проведение анкетного исследования мордвы по разным возрастам показало, что среди них быстро исчезли знания этнических материальных традиций, более устойчивыми оказались духовно-обрядовые ритуалы. Мордовские переселенцы 1920-х гг. уже к 1950-м гг. отказывались в повседневной жизни использовать традиционную одежду и хранили ее как реликвию. Приезжающие в 1950-1960-е гг. целинники привозили из Мордовии элементы традиционной одежды, которые вызывали уже удивление у давно живущих переселенцев. В сохранении духовных ритуалов важную роль сыграли крепкие внутриэтнические брачносемейные связи. Они сохраняли внутреннюю этническую среду и способствовали передаче традиций. Как выразился один из информаторов с. Подсинее Алтайского района Хакасии, А.И. Степанов (1940 г.р., мордва-мокша), «вокруг жила одна мордва, так и женились друг на друге» ${ }^{30}$.

Послевоенные миграционные волны мордвы из Мордовии позволили сохранить языковую среду. В настоящее время в Хакасии, Красноярском крае основными носителями мордовского языка остались представители старшего поколения, которые родились в моноэтнических селах или приехали в Сибирь из Мордовии в 1940-1950-е гг. Они на русском языке говорят с акцентом, сильно растягивая слова, смешивая два языка. При этом анкетирование этого поколения показало, что $98 \%$ не умеют читать и писать на своем мордовском языке. Среднее поколение (1960-1970-х гг.р.) свободно владеет двумя языками, при этом очень хорошо говоря на русском. В селах Подсинее, Краснополье в бытовом общении, дома, на улице, в магазине бытует двуязычие.

\footnotetext{
${ }^{27}$ Полевой дневник, 2012 г. Республика Хакасия, Каратузский район, с. Алексеевка. Кудашкина П.И., 1930 г.р., мордва-мокша.

${ }^{28}$ Список населенных мест Сибирского края. 1929. Т. 2. Округа Северо-Восточной Сибири. 557 с.

${ }^{29}$ ПМА. Полевой дневник, 2012 г. Республика Хакасия, Алтайский район, с. Краснополье. Алексеенко Н.Н., 1960 г.р., мордва-мокша.

${ }^{30}$ ПМА. Полевой дневник, 2012 г. Республика Хакасия, Алтайский район, с. Подсинее. Степанов А.И., 1940 г.р., мордва-мокша.
} 
Как правило в сибирских селах вопрос об образовании на мордовских языках не ставился. Эта тенденция была связана с низким уровнем социализации мордовских семей. Переселялись из Мордовии в Сибирь крайне бедные многодетные семьи, в которых вопрос об образовании не поднимался. Как рассказывают сами информаторы, «начинали писать и увидели учебники, они впервые только в Сибири, и пошли в школу, когда им было 9-10 лет». Некоторых и не брали в первый класс, «говорили, идите годик русскому языку поучитесь и приходите» ${ }^{31}$. Среднее поколение (1960-1970-х гг.р.), осваивало с рождения два языка, мордовский язык дома, а русский - в школе, утратило навыки разговорной речи (96 \%), сохраняя понимание языка. В дальнейшем многие представители среднего поколения столкнулись с проблемой невостребованности родного языка в жизни; в основном он служил для общения с родителями.

Респонденты отмечали, что мордовский язык даже мешал им в учебе, затруднял усвоение учебной программы: «Когда мы пришли в первый класс, мы тупые, ничего не знаем, нас русскому языку учат, а мы ничего не понимаем» ${ }^{32}$. Негативные тенденции закладывались при обучении детей в малокомплектных школах, после которых дети продолжали учиться в средних школах, проживая в интернате. В это время у детей формировалось негативное отношение к собственному этносу. В связи с этим родители старались как можно больше оградить своих детей от влияния собственной культуры и языка, пытаясь тем самым облегчить им жизнь. В результате представители младшего поколения мордвы (1980-2000 г.р.) уже не знают мордовского языка, родным определяют русский язык. Эти тенденции наравне с государственной политикой уже у третьего поколения мордовских жителей сформировали двойственную позицию: только 25 \% считают себя мордвой, из них 5 \% владеют мордовским языком на бытовом уровне, но не считают его родным.

Важным показателем происходящих среди мордвы этнических процессов является распространение мордовско-русского двуязычия, которое в течение нескольких поколений и в настоящий момент классифицируется как этнический признак мордвы. В этносоциологии принято различать экстенсивную и интенсивную тенденции развития двуязычия. Среди мордвы Сибири все больше, наравне с родным языком, владеют вторым языком - русским, который становится основным при общении. Во втором случае проявляется тенденция к «углублению» двуязычия посредством использования второго языка во внутриэтническом общении ${ }^{33}$. Среди мордвы Сибирского региона, как в местах компактного, так и дисперсного проживания наблюдаются обе эти тенденции, поскольку широкое владение русским языком представлено и на межэтническом, и на бытовом внутриэтническом уровне.

Представители старшего поколения, в полном объеме владевшие культурно-бытовыми навыками, назвали этнодифференцирующими признаками обряды жизненного цикла: свадебный (61\%) и похоронный (29\%). Но в силу ряда объективных и субъективных причин они не передали детям свои умения и знания. Среди представителей среднего и особенно младшего поколения знание семейной обрядности практически отсутствует. Они затруднялись определить обряды, свойственные мордве, и на первое место после языка поставили особенности характера.

В Красноярской зоне состояние языка и уровень самосознания мордвы менялись от периода к периоду, начиная с ее появления в регионе. В регионе сложились зоны компактных моноэтнических поселений, в которых сформировались эрзянский и мокшанский ареалы, в их рамках долгое время сохранялись аутентичные языковая среда и самосознание. При отсутствии условий полноценного этнокультурного развития (отсутствие школ с преподаванием национального языка, национально-культурных центров) начинаются активные асси-

\footnotetext{
${ }^{31}$ ПМА. Полевой дневник, 2012 г. Республика Хакасия, Алтайский район, с. Краснополье. Кетова Е.К., 1927 г.р., мордва-мокша.

32 ПМА. Полевой дневник, 2012 г. Республика Хакасия, Алтайский район, с. Краснополье. Осипова М.С., 1927 г.р., мордва-мокша.

${ }_{33}^{3}$ Брук С.И., Губогло М.Н. Факторы распространения двуязычия у народов СССР // Советская этнография. 1975. № 5. С. 18-19.
} 
миляционные процессы не только среди городского, но и среди сельского мордовского населения. В целом состояние мордовского этноса в Красноярской зоне на протяжении XX в. характеризуется размыванием этнического сознания. Основными носителями мордовской культуры и самосознания в деревнях региона остаются представители старшего поколения, которые родились и воспитывались в моноэтнических селах или приехали из Мордовии. Поэтому у них не существует проблем с этническим самоопределением. Второе поколение, которое уже родилось в Сибири, формировалось в полиэтническом окружении, где имела место установка «не выделяться, не отличаться от других». При всех социокультурных и политико-административных изменениях проявлением самосознания современной мордвы попрежнему является идентификация себя в рамках субэтнических групп - мокша и эрзя. В полевых исследованиях часть респондентов называли себя просто мордвой, не зная точного происхождения, что свидетельствует о снижении степени этничности.

В Красноярском крае, Хакасии современная языковая ситуация к началу XXI в. характеризуется широким распространением билингвизма, что в значительной степени определялется интенсивностью межэтнических контактов. Процессы трансформации языковой культуры мордвы совпадали с процессами трансформации ее идентичности.

\section{Jumepamypa}

Бережнова М.А. Государственная программа переселений в восточные районы СССР 1939-1942 гг.: этнографический аспект // Известия Алтайского государственного университета. (История и археология). 2008. № 4/2. С. 7-15.

Брук С.И., Губогло М.Н., Факторы распространения двуязычия у народов СССР // Советская этнография. 1975. № 5. С. 18-33.

Восточный вектор переселенческой политики в СССР. Конец 1920-х - конец 1930-х гг. Новосибирск: Институт истории СО РАН, 2007. 358 с.

Всероссийская перепись населения 1939 года. Национальный состав населения районов, городов и крупных сел РСФСР [Электронный ресурс]. URL: www.demoscope.ru

Всесоюзная перепись населения 1926 год. Отдел. 1. М., 1928. Т. VI. Сибирский край. Бурято-Монгольская АССР. (Население по народности, родному языку). 389 с.

Занданова Л.В. Переселение крестьянства в Азиатскую Россию: (конец 1940-х - сер. 60-х гг. ХХ в.). Иркутск, 1997. 157 с.

Иванов А.С. Калмыки в Западной Сибири (1944-1956 гг.): особенности социализации на спецпоселении // Вестник археологии, антропологии и этнографии. 2011. № 2 (15). С. 210-217.

Ильиных B.A. Социальные аспекты миграционных процессов в Сибири первой трети XX века // Миграционные процессы в азиатской России в XIX - начале XXI в.: сб. науч. тр. / отв. ред. В.А. Исупов. Новосибирск, 2009. С. 44-53.

Исупов В.А. Индивидуальные крестьянские переселения в города Западной Сибири (конец 1920-х - начало 1940-х гг.) // Миграционные процессы в азиатской России в XIX начале XXI в.: сб. науч. тр. / отв. ред. В.А. Исупов. Новосибирск, 2009. С. 66-93.

Красильников С.А. Государственная политика в сфере плановых и принудительных переселений в Сибири (вторая половина 1920-х - 1930-е годы) // Проблемы истории, русской книжности, культуры и общественного сознания. Новосибирск, 2000. С. 314-322.

Массовые аграрные переселения на восток России (конец XIX - середина XX в.) / Н.Н. Аблажей, С.А. Красильников, Д.Д. Миненков, Г.А. Ноздрин. Новосибирск: НГУ, 2010. 206 c.

Миграции населения Азиатской России: конец XIX - начало XX в. / отв. ред. В.А. Исупов. Новосибирск: Параллель, 2011. 392 с.

Надькин Т.Д. Сталинская аграрная политика и крестьянство Мордовии. М.: РОССПЭН, 2010. 331 c.

Овчарова М.А. Мордва Алтая: История и этнокультурные процессы (XIX - начало XXI века). Новосибирск, 2010. 228 с. 
Первая всеобщая перепись населения Российской империи 1897 г. / под. ред. Н.А. Троицкого. СПб.: издание Центрального статистического комитета Министерства внутренних дел. 1899-1905. T. LXXXIII. Енисейская губерния. 185 с.

Платунов Н.И. Переселенческая политика советского государства и ее осуществление в СССР (1917 - июнь 1941 г.). Томск, 1976. 282 с.

Полян П.М. «Не по своей воле...» История и география принудительных миграций в СССР. М.: Мемориал, 2001. 244 с.

Список населенных мест Российской империи по сведениям 1859 года. Енисейская губерния. СПб., 1864 г. Т. 51.74 с.

Список населенных мест Сибирского края / ЦСУ. Сибирский Краевой статистический отдел. Новосибирск, 1928. Т. 1. Округа Юго-Западной Сибири. 831 с.

Список населенных мест Сибирского края / ЦСУ. Сибирский Краевой статистический отдел. Новосибирск, 1929. Т. 2. Округа Северо-Восточной Сибири. 557 с.

Шиловский М.В. Основные потоки внешних миграций в истории Сибири ХХ века // Миграционные процессы в азиатской России в XIX - начале XXI в.: сб. науч. тр. / отв. ред. В.А. Исупов. Новосибирск, 2009. С. 32-44.

Щеглова T.К. Деревня и крестьянство Алтайского края в XX веке. Устная история. Барнаул, 2008. 528 с.

Щеглова Т.К. Устная история: учеб. пособие. Барнаул, 2011. 364 с.

\section{References}

Ablazhey, N.N., Krasilnikov, S.A., Minenkov, D.D., Nozdrin, G.A. (2010). Massovye agrarnye pereseleniya na vostok Rossii (konets $X I X$ - seredina $X X$ v.) [Mass agricultural migration to the East of Russia (late $19^{\text {th }}-$ mid $20^{\text {th }}$ century)]. Novosibirsk, NGU. 206 p.

Berezhnova, M.A. (2008). Gosudarstvennaya programma pereseleniy v vostochnye rayony SSSR 1939-1942 gg.: etnograficheskiy aspect [State program of resettlement to the Eastern regions of the USSR in 1939-1942: ethnographic aspect]. In Izvestiya Altayskogo gosudarstvennogo universiteta. (Istoriya i arkheologia). No. 4/2, pp. 7-15.

Bruk, S.I., Guboglo, M.N., (1975). Faktory rasprostraneniya dvuyazychiya u narodov SSSR [Factors of bilingualism spread among the peoples of the USSR]. In Sovetskaya Etnografia. No. 5, pp. 18-33.

Il'inykh, V.A. (2009). Sotsialnye aspekty migratsionnykh protsessov v Sibiri pervoy treti XX veka [Social aspects of migration processes in Siberia of the first third of the $20^{\text {th }}$ century]. In V.A. Isupov (Ed.). Migration processes in Asian Russia in the $19^{\text {th }}-$ early $21^{\text {th }}$ centuries. Collection of scientific works. Novosibirsk, pp. 44-53.

Isupov, V.A. (2009). Individualnye krestyanskie pereseleniya v goroda Zapadnoy Sibiri (konetc 1920-kh - nachalo 1940-kh gg.) [Individual peasant migrations to the cities of Western Siberia (late 1920s - early 1940s)]. In V.A. Isupov (Ed.). Migration processes in Asian Russia in the $19^{\text {th }}-$ early $21^{\text {th }}$ centuries. Collection of scientific works, Novosibirsk, pp. 66-93.

Isupov, V.A. (Ed.). (2011). Migratsii naseleniya Aziatskoy Rossii: konets XIX - nachalo XX v. [Migration of the population of Asian Russia: the end of the $19^{\text {th }}$ - beginning of the $20^{\text {th }}$ centuries]. Novosibirsk, Parallel. 392 p.

Ivanov, A.S. (2011). Kalmyki v Zapadnoy Sibiri (1944-1956 gg.): osobennosti sotsializatsii na spetsposelenii [Kalmyks in Western Siberia (1944-1956): features of socialization in a special settlement]. In Vestnik arkheologii, antropologii i etnigrafii. No. 2 (15), pp. 210-217.

Krasilnikov, S.A. (2000). Gosudarstvennaya politika v sfere planovykh i prinuditelnykh pereseleniy v Sibiri (vtoraya polovina 20-kh - 1930-e gody) [State policy in the sphere of planned and forced relocations in Siberia (the second half of the 20s-1930s)]. In Problems of history, Russian literature, culture and public consciousness. Novosibirsk, pp. 314-322.

Nad'kin, T.D. (2010). Stalinskaya agrarnaya politika i krestyanstvo Mordovii [Stalinist agrarian policy and the peasantry of Mordovia]. Moscow, ROSSPEN, $331 \mathrm{p}$. 
Ovcharova M.A. (2010). Mordva Altaya: Istoriya i etnokulturnye protsessy (XIX - nachalo XXI veka) [Altai Mordva: History and ethno-cultural processes $\left(19^{\text {th }}-\right.$ beginning of the $21^{\text {th }}$ century)]. Novosibirsk. 228 p.

Platunov, N.I. (1976). Pereselencheskaya politika sovetskogo gosudarstva i ee osushchestvlenie $v$ SSSR (1917 - iyun 1941 g.) [Migration policy of the Soviet state and its implementation in the USSR (1917 - June 1941)]. Tomsk. 282 p.

Polyan P.M. (2001). “Ne po svoey vole...” Istoriya i geografiya prinuditelnykh migratsiy $v$ SSSR ["Not by my own will..." History and geography of forced migrations in the USSR]. Moscow, Memorial. 244 p.

Shcheglova, T.K. (2008). Derevnya i krestyanstvo Altayskogo kraya v XX veke. Ustnaya istoriya [Village and peasantry of the Altai territory in the $20^{\text {th }}$ century. Oral history]. Barnaul, $528 \mathrm{p}$.

Shcheglova, T.K. (2011). Ustnaya istoriya: uchebnoe posobie [Oral history: studies. Stipend.]. Barnaul, 364 p.

Shilovskiy, M.V. (2009). Osnovnye potoki vneshnikh migratsiy v istorii Sibiri XX veka [Main flows of external migrations in the history of Siberia of the $20^{\text {th }}$ century] In V.A. Isupov (Ed.). Migration processes in Asian Russia in the XIX - early XXI centuries. Collection of scientific works. Novosibirsk, pp. 32-44.

(1864). Spisok naselennykh mest Rossiyskoy imperii po svedeniyam 1859 goda. Eniseyskaya guberniya [List of localities in the Russian Empire according to data from 1859. Yenisei province]. St. Petersburg, Vol. 51. 74 p.

(1928). Spisok naselennykh mest Sibirskogo kraya [List of localities in the Siberian region]. In TsSU. Sibirskiy Kraevedcheskiy Otdel. Novosibirsk, Vol. 1. Okruga Yugo-Zapadnoy Sibiri [Districts of South-Western Siberia]. $831 \mathrm{p}$.

(1929). Spisok naselennykh mest Sibirskogo kraya [List of localities in the Siberian region]. In TsSU. Sibirskiy Kraevedcheskiy Otdel. Novosibirsk, Vol. 2. Okruga Severo-Vostochnoy Sibiri [Districts of North-Eastern Siberia]. 557 p.

Troitsky, N.A. (Ed.). (1899-1905). Pervaya vseobshchaya perepis naseleniya Rossiyskoy imperii $1897 \mathrm{~g}$. [The first General census of the population of the Russian Empire in 1897]. Yenisei province. St. Petersburg, Izdaniye Statisticheskogo komiteta Ministerstva vnutrennikh del. Vol. LXXXIII. 185 p.

(2007). Vostochniy vektor pereselencheskoy politiki v SSSR. Konets 1920-kh - konets 1930-kh gg. [The Eastern vector of resettlement policy in the USSR. Late 1920s - late 1930s], Novosibirsk, Institut istorii SO RAN. 358 p.

Vserossiyskaya perepis naseleniya 1939 goda. Natsionalny sostav naseleniya rayonov, gorodov i krupnykh sel RSFSR [All-Russian population census of 1939. The national composition of the population of districts, cities and large villages of the RSFSR]. URL: www.demoscope.ru

(1928). Vsesoyuznaya perepis naseleniya 1926 god [All-Union population census 1926]. Department 1. Moscow. T. VI. Sibirskiy kray. Buryato-Mongolskaya ASSR. (Naselenie po narodnosti, rodnomu yazyku). Vol. VI. Siberian region. Buryat-Mongolian ASSR. (Population by nationality, native language)]. $389 \mathrm{p}$.

Zandanova, L.V. (1997). Pereselenie krestyanstva v Aziatskuyu Rossiyu: (konets 1940-kh - ser. 60-kh gg. $X X$ v.) [Migration of the peasantry to Asian Russia: (the end of the 1940s - ser. 60s of the $19^{\text {th }}$ century)], Irkutsk. 157 p.

Статья поступила в редакцию 07.07.2020 г. 